\title{
High-Selectivity Polysiloxane Membranes for Gases and Liquids Separation (A Review)
}

\author{
E. A. Grushevenko ${ }^{a, *}$, I. L. Borisov ${ }^{a}$, and A. V. Volkov ${ }^{a}$ \\ ${ }^{a}$ Topchiev Institute of Petrochemical Synthesis, Russian Academy of Sciences, Moscow, 119071 Russia \\ *e-mail: evgrushevenko@ips.ac.ru
}

Received June 30, 2021; revised July 15, 2021; accepted July 28, 2021

\begin{abstract}
The most promising approaches to making polysiloxane-based membranes more selective are considered. These approaches can be subdivided into three groups: (1) development of new membrane materials by copolymerization, (2) modification of the polysiloxane chain (in the backbone and pendant chains), and (3) development of mixed matrix membranes. All the three approaches are subjected to a critical analysis, and conclusions are made on the prospects for the development of high-selectivity materials and high-performance membranes based on them. The data are presented from the viewpoint of applied aspects of polysiloxane-based membranes.
\end{abstract}

Keywords: silicone rubbers, polydimethylsiloxane, membranes, membrane technology, pervaporation, gas separation, vapor separation, polyorganosiloxanes

DOI: $10.1134 / \mathrm{S} 0965544121090103$

Membrane technologies are widely used in separation of gaseous and liquid media, in particular, in oil refining, gas processing, and petroleum chemistry [1-4]. The examples of such separations are nitrogen separation from air [5-7], helium separation from natural gas $[8,9]$, hydrogen separation from process streams [10-13], trapping of highly volatile organic compounds from air media $[1,14]$, etc.

Polysiloxanes (silicone rubbers) as polymeric membrane materials have found wide use in commercial membrane productions $[2,15]$. These materials are mainly used for such processes as gas separation [16], vapor separation [17], and pervaporation [4].

In nonporous membrane materials, the transport of gases and vapors occurs by the dissolution-diffusion mechanism [18]. Siloxane rubbers belong to the group of membrane materials for which the solubility factor makes the decisive contribution to the membrane selectivity. Thus, polysiloxane membranes will mainly transmit readily condensing compounds $\left(\mathrm{C}_{3+}\right.$ hydrocarbons, alcohols, low-boiling organic compounds, etc.), which often are bulky organic molecules.
The best studied and the most widely used polysiloxane is polydimethylsiloxane (PDMS), a highly permeable material [19-22]. This property is caused by high flexibility of the polysiloxane chain $\left(T_{\mathrm{g}}(\mathrm{PDMS})=\right.$ $\left.-125^{\circ} \mathrm{C}[23,24]\right)$. At room temperature, PDMS is in the hyperelastic state; therefore, its chemical cross-linking is required to ensure the required mechanical properties $[25,26]$. On the other hand, PDMS demonstrates relatively low selectivity of separating gases, e.g., air components or lower hydrocarbons (the ideal selectivity is as follows: $\mathrm{CO}_{2} / \mathrm{N}_{2}=9.5$ [27] and $n-\mathrm{C}_{4} \mathrm{H}_{10} / \mathrm{CH}_{4}=$ 17 (for $3 \% n-\mathrm{C}_{4} \mathrm{H}_{10} / 97 \% \mathrm{CH}_{4}$ binary mixture, 5 [21]). Therefore, much attention is paid to the development of materials and membranes based on polysiloxanes with enhanced separation characteristics [16, 28-31]. Both chemical (cross-linking [32], copolymerization [33], modification of the backbone [34] and pendant chains [31], etc.) and physical methods of polysiloxane design (preparation of mixed matrix membranes with zeolites $[35,36]$, activated carbons [37], silicalites [38], etc.) are used for the development of high-selectivity membrane materials based on polysiloxanes. 
Scheme 1. Synthesis of polystyrene-polysiloxane copolymers [47].
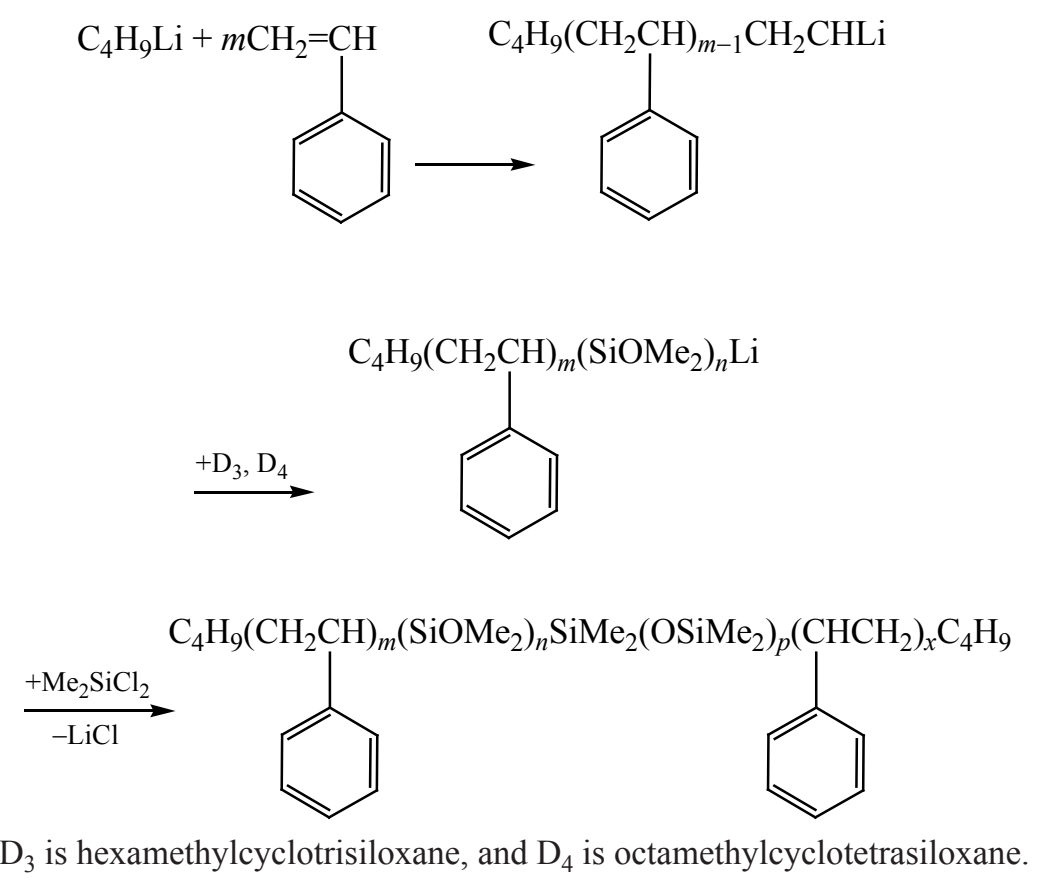

Here we consider the most promising approaches to enhancing the selectivity of polysiloxane-based membranes and the main fields of their use in membrane technology.

\section{DEVELOPMENT OF NEW MEMBRANE MATERIALS BY COPOLYMERIZATION}

Copolymerization of various monomers is one of widely used approaches to the design of membrane materials. Modern synthetic possibilities allow the development and synthesis of block copolymers with a wide spectrum of physical and chemical properties. The ratio of the organic and inorganic blocks determines the membrane properties of a material (permeability, selectivity, mechanical properties). Such approach allows preparation of new membrane materials with improved properties. For example, the presence of rigid block based on glassy polymers in the siloxane chain improves the mechanical properties and film-forming ability with the preservation of high permeability coefficients [39-41]. Copolymerization of siloxanes is also performed jointly with polycarbonates [42], polystyrene [33], poly(alkyl methacrylates) [30], polyesters [43], and polysilphenylenesiloxane [44, 45]; however, the mutual compatibility of the polysiloxane and hydrocarbon chains is limited. As noted by Raigorodskii et al. [40], thermodynamic and mechanical incompatibility of organic and organosilicon blocks causes aggregation of each of them into separate phases and formation of a two-phase morphology, which can lead to phase segregation. For example, Beckman and Teplyakov note [46] that a blend of two continuous phases in polyvinyltrimethylsilane (PVTMS)-PDMS block copolymers can be formed only at the PDMS content in the interval from 25 to $40 \mathrm{vol} \%$. At the PDMS content higher than 40 vol \%, the system is a dispersion of platelike PVTMS particles in a PDMS medium. At the PDMS content of the block copolymer lower than $25 \mathrm{vol} \%$, the two-phase system consists of needle-like PDMS particles dispersed in PVTMS.

In preparation of polyorgano-polysiloxane block copolymers, the initial organosilicon compounds can be diverse: cyclosiloxanes, unsaturated siloxanes, and silicon- and carbofunctional siloxanes; they can also contain various active groups. Such copolymers are prepared by polymerization, polymerizationpolycondensation, and polycondensation methods [40]. 
Scheme 2. Scheme of ring opening polymerization of cyclocarbosiloxane with $n$-methylene groups [57].

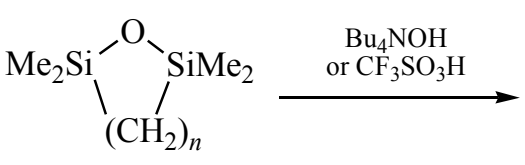

For example, polystyrene-polysiloxane was prepared by living polymerization (Scheme 1) [47].

Introduction of $40 \mathrm{~mol} \%$ polystyrene into PDMS by block polymerization allowed the separation factor to be increased by a factor of 7.5 and the permeability in pervaporation separation of a $0.05 \mathrm{wt} \%$ benzene/water mixture, by $20 \%$ [33]. Uragami et al. [33] note that such effect is caused by an increase in the benzene sorption in the block copolymer compared to pure PDMS.

Matsumoto et al. [48] described multiblock copolymers containing units of PDMS and aromatic polyamides (the PDMS amount in the copolymer was varied from 26 to 75 wt \%). The oxygen and nitrogen permeability coefficients of the polymer films obtained increased with an increase in the fraction of siloxane blocks. At $75 \%$ siloxane content of the copolymer, the oxygen permeability coefficient was 224 Barrer $^{1}$ and the oxygen/ nitrogen selectivity was 2.3 , whereas for the copolymer containing $46 \%$ siloxane the oxygen permeability coefficient was 41 Barrer and the oxygen/nitrogen selectivity was 2.4. Introduction of siloxane blocks into the rigid-chain polyamide increases the segmental mobility of the chain, which, in turn, increases the permeability coefficient.

Siloxane block copolymers have a number of advantages over traditional silicone rubbers due to good mechanical and film-forming properties. Composite gas-separation membranes with the selective layer based on a block copolymer of $\alpha, \omega$-bis(diethylamino)diorganosiloxane oligomer with phenylsilsesquioxane (Lesto-sil ${ }^{\mathrm{TM}}$ ), synthesized at Polimersintez (Vladimir, Russia), were prepared at the Vladipor Scientific and Technical Center (Vladimir, Russia) [49-52]. A hollowfiber membrane of polysiloxane-polycarbonate block copolymer $\left(\right.$ Karbosil $\left.^{\mathrm{TM}}\right)$ synthesized at the State Research

\footnotetext{
${ }^{1}$ Barrer $=1 \times 10^{-10} \mathrm{~cm}^{3} \mathrm{~cm} \mathrm{~cm}^{-2} \mathrm{~s}^{-1}\left(\mathrm{~cm} \mathrm{Hg}^{-1}\right.$.
}

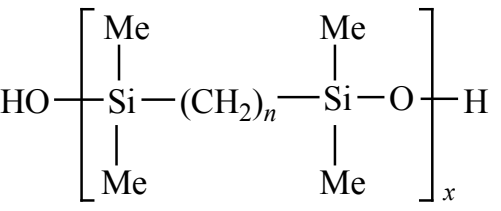

Institute of Chemistry and Technology of Organoelement Compounds (Moscow, Russia) was developed at Khimvolokno Production Association (Mytishchi, Moscow oblast, Russia) [51, 52]. A block copolymer of oligoarylate with oligodimethylsiloxane, named Silar, was also synthesized [52, 53]. Membranes based on these copolymers are presently produced by Vladipor; this is the series of MDK gas-separation composite membranes. ${ }^{2}$ These membranes exhibit high, compared to PDMS, separation characteristics, and their preparation does not involve chemical cross-linking [52]. Borisov et al. [44] have shown that MDK-3 membrane (Vladipor) with the selective layer made of polydimethylsiloxanepolyphenylsilsesquioxane copolymer exhibits higher separation factor in thermopervaporation separation of a 1 wt $\% n$-butanol-water mixture (11.5) compared to the Pervatech PDMS commercial membrane with the PDMSbased selective layer (7.8), developed by Pervatech (Netherlands) for organophilic pervaporation.

\section{MODIFICATION OF POLYSILOXANES IN THE BACKBONE AND PENDANT CHAINS}

Chemical modification of polysiloxanes is performed in the course of polymerization or polymer-analogous transformations. This approach is aimed at incorporation of hydrocarbon or functionalized fragments into the backbone [31, 54-58] or pendant chains $[29,31,56,59]$ of polysiloxane.

Backbone modification. Such modification of the polymethylsiloxane backbone is performed in the course of polymerization of the corresponding cyclocarbosiloxanes by ring opening (Scheme 2) [57, $60,61]$ or by hydrolytic polycondensation (Scheme 3 ) [62-64].

\footnotetext{
${ }^{2}$ Gas-separation composite membranes of MDK type, Vladipor. http://www.vladipor.ru/catalog/\&cid=008.
} 
Scheme 3. Scheme of hydrolytic polycondensation of (1-naphthyl)phenylvinyl-(-)-menthoxysilane to obtain poly[\{(1S)-1-(1naphthyl)-1-phenyl-3,3-dimethyldisiloxane-1,3-diyl \}ethylene] (adapted from [62]).

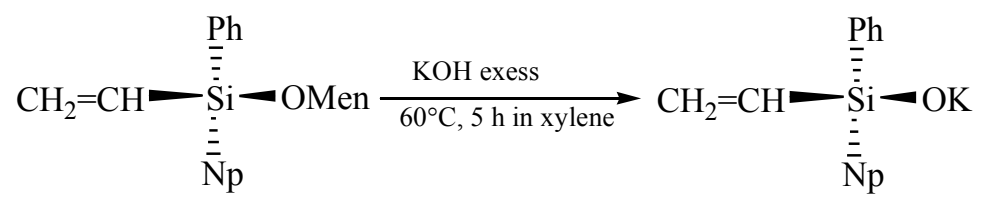

(1-Naphthyl)phenylvinyl-(-)-menthoxysilane
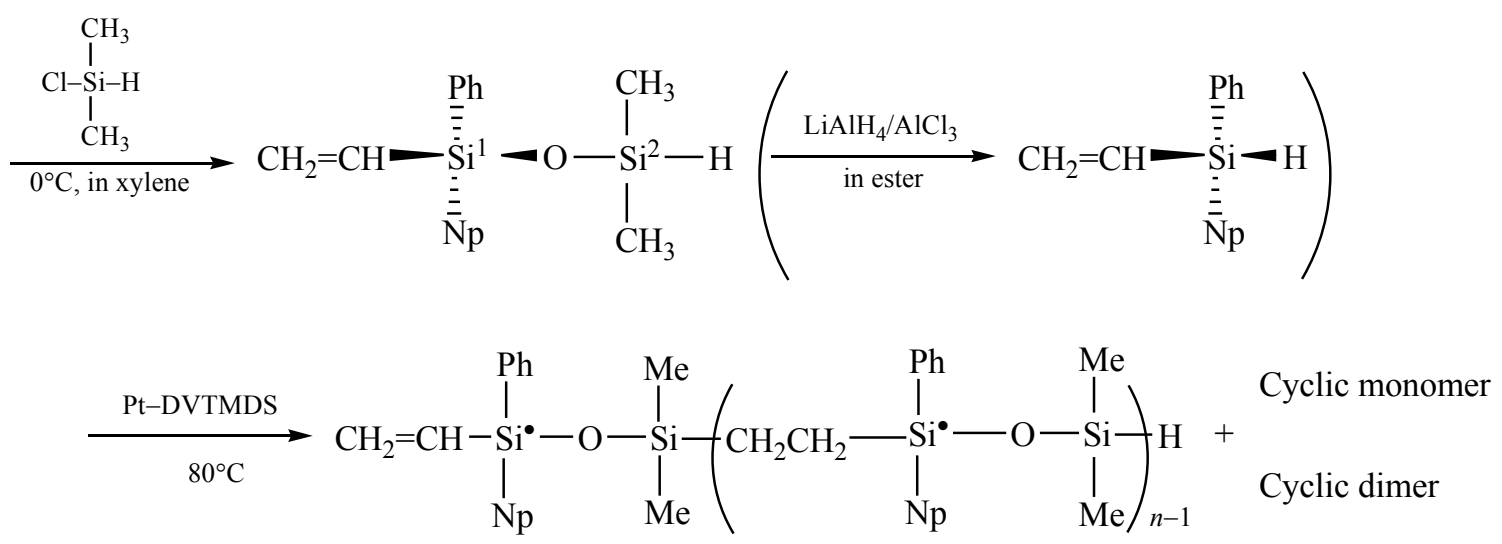

Studies on the synthesis of cyclocarbosiloxanes and polydimethylsilalkylenes and on transport properties of membranes based on them are relatively few [31, 55-58]. Borisov et al. [34] studied the gastransport properties of polydimethylsildimethyleneand polydimethylsiltrimethylenedimethylsiloxane. Introduction of three methylene fragments into the PDMS backbone leads to a decrease in the $n$-butane permeability coefficient from 14000 to 6600 Barrer $^{3}$ with a simultaneous increase in the ideal $n$-butane/ methane separation selectivity from 11 to 15 . Thus, variation of the length of the hydrocarbon fragment in the polycarbosiloxane backbone can be used for developing a more selective membrane material for separation of lower hydrocarbons. Stern et al. [31] studied the influence of the structure of the hydrocarbon fragment in the polydimethylsiloxane backbone. They examined the polymers containing linear aliphatic fragments (2, 6, 8 methylene groups) and phenylene groups with the silicon atoms in the $o$ - and $p$-positions. They note that introduction of bulky hydrocarbon fragments into

\footnotetext{
${ }^{3}$ Here and hereinafter, the gas permeability coefficient was measured at $30^{\circ} \mathrm{C}$ and a pressure tending to zero (unless otherwise indicated).
}

the polysiloxane backbone leads to a decrease in the gas permeability of the polymers (the permeability coefficient decreased from 933 to 11 Barrer for oxygen and from 4553 to 64 Barrer for carbon dioxide) and to an increase in the separation selectivity (the oxygen/nitrogen separation selectivity increased from 2.0 to 3.3). However, these approaches suggest multistep synthesis of the starting monomers [65]. In addition, e.g., cyclic carbosiloxanes are prepared in a low yield, which makes topical further search for optimum monomer synthesis procedures [66].

Pendant chain modification. Polyorganosiloxanes with various pendant substituents can be prepared both by polymerization [67] and by polymer-analogous transformations [68-70]. Such approaches as hydrolytic polycondensation were used (Scheme 4). The polycondensation mechanism in the presence of water is presented in more detail in Scheme 5 [67]. It should be noted that this procedure is a multistep synthesis from chlorosilanes to carbofunctional organosilicon compounds [67].

The second procedure for preparing polysiloxanes substituted in the pendant chain, suggested for the first time in [29], consists in modification of the siloxane chain by polymer-analogous transformations. Such substituted 
Scheme 4. Preparation of polyorganosiloxanes by polycondensation.

$$
\begin{gathered}
p\left[\mathrm{R}_{2} \mathrm{SiO}\right]_{4}+\mathrm{AB} \stackrel{\text { cat. }}{\longrightarrow} \mathrm{AO}\left[\mathrm{R}_{2} \mathrm{SiO}\right]_{d} \mathrm{~B}+\left[\mathrm{R}_{2} \mathrm{SiO}\right]_{z} \\
\mathrm{AB}=\mathrm{H}_{2} \mathrm{O}, \mathrm{R}_{3} \mathrm{SiOSi}\left(\mathrm{X}_{2}\right) \mathrm{R}, \mathrm{R}_{n} \mathrm{SiX}_{4-n} ; \mathrm{R}=\mathrm{H} \text {, aliphatic, aromatic, carbofunctional substituent; } n=0-3 .
\end{gathered}
$$

Scheme 5. Polycondensation mechanism.

$$
\begin{gathered}
q \mathrm{R}_{n} \mathrm{SiX}_{4-n}+z \mathrm{R}_{m}^{1} \mathrm{SiX}_{4-n} \stackrel{+\mathrm{H}_{2} \mathrm{O}}{-\mathrm{HX}}\left[\mathrm{R}_{n} \mathrm{Si}(\mathrm{OH})_{4-n-p} \mathrm{O}_{p / 2}\right]_{q}\left[\mathrm{R}_{m}^{1} \mathrm{Si}(\mathrm{OH})_{4-m-p} \mathrm{O}_{p / 2}\right. \\
\longrightarrow\left[\mathrm{R}_{n} \mathrm{Si}(\mathrm{OH})_{(4-n) / 2}\right]_{q}\left[\mathrm{R}_{m}^{1} \mathrm{SiO}_{(4-m) / 2}\right]_{z}
\end{gathered}
$$

$\mathrm{X}=$ halogen, alkoxy, aroxy, acyloxy, amino, or other readily hydrolyzable group; $\mathrm{R}, \mathrm{R}^{1}=\mathrm{H}$, aliphatic, aromatic, carbofunctional substituent; $n=0-3$.

Scheme 6. Synthesis of modified polymethylsiloxane.<smiles>[R]CC[Si](C)(O[Si](C)(C)C)C(C)(C)[Si](C)(C)O[Si](C)(C)O[Si](C)(C)C</smiles>

polysiloxanes are prepared by hydrosilylation, namely, by the reaction of polymethylhydrosiloxane (PMHS) with 1-alkene in the presence of a Pt-containing catalyst (Karstedt or Speier catalyst) (Scheme 6) [63].

Stern et al. [31] studied the gas-transport properties of polymethylsiloxanes with different pendant groups, including the methyl, ethyl, propyl, octyl, and phenyl groups. The glass transition point increased with an increase in the substituent volume, which means that the polymer chain mobility decreases. As a consequence, the oxygen permeability coefficient decreased in the series of substituents methyl-ethyl-propyl-octyl-phenyl: 933-312-383-190-32 Barrer, respectively. The oxygen/ nitrogen selectivity increased from 2.0 to 3.1 with an increase in the pendant substituent volume [31].

Lee et al. [56] studied how the polymer pendant chain structure influences the oxygen and nitrogen permeability of silicone polymers of the general formula (MeRSiO) where $\mathrm{R}$ is alkyl, aryl, or $\mathrm{CH}_{2} \mathrm{CH}_{2} \mathrm{CF}_{3}$. As they found, with an increase in the alkyl group size from $\mathrm{C}_{1}$ to $\mathrm{C}_{8}$, the permeability coefficient appreciably decreased (for $\mathrm{O}_{2}$, from 78 to 20 Barrer), whereas the $\mathrm{O}_{2} / \mathrm{N}_{2}$ selectivity increased (from 2.10 to 2.29). Introduction of the benzene ring into the polysiloxane pendant chain led to a decrease in the permeability coefficient by more than an order off magnitude (2.5 Barrer) and to an increase in the $\mathrm{O}_{2} / \mathrm{N}_{2}$ selectivity to 2.98 compared to linear alkyl substituents.

Ashworth et al. [59] studied how the pendant ester group influences the gas permeability of polysiloxane polymers. As they showed, with an increase in the content of ester groups from 0 to $24.1 \%$ the $\mathrm{CO}_{2}$ solubility coefficient increased. As a consequence, the $\mathrm{CO}_{2} / \mathrm{CH}_{4}$ selectivity increased from 3.14 to 3.92 . 
In [71], we suggested performing the modification of polymethylhydrosiloxane with 1-alkene and crosslinking with 1,7-octadiene in situ in the presence of Karstedt catalyst. Such approach allowed preparation of membranes from polyalkylmethylsiloxanes in one step. Performing the modification and cross-linking by hydrosilylation allows also using a single catalyst, which improves the economic efficiency of this approach. The simplicity of the suggested procedure allowed us to study in our subsequent works how various crosslinking agents influence the gas-transport properties of membranes based on polyoctylmethylsiloxane (POMS) [72] and polydecylmethylsiloxane [73]. As we showed, an increase in the length of the cross-linking agent, divinyltetramethyldisiloxane-PDMS $\left(M_{\mathrm{n}}=\right.$ $25000 \mathrm{~g} \mathrm{~mol}^{-1}$ ), leads to a decrease in the ideal $n$-butane/ methane selectivity from 26 to 22 and to an increase in the permeability coefficient (from 9600 to 9800 Barrer at the pressure over the membrane of 0.8 bar) [72].

Chemical cross-linking. The majority of polysiloxanes are viscous liquids at room temperature. To prepare continuous membranes with the required mechanical characteristics, chemical cross-linking of the polymer via functional groups is performed. The most widely used procedure is cross-linking with alkoxysilanes via terminal silanol groups of the polymer in the presence of tin catalysts [29, 34, 59, 74-76]. The use of functional alkoxysilanes $\mathrm{R}^{\prime} \mathrm{Si}(\mathrm{OR})_{3}$ (for example, $\mathrm{R}^{\prime}$ is vinyl [75] or phenyl [74] groups) allows preparation of PDMWS with different levels of cross-linking density, glass transition point, hydrophobicity, and transport properties. For example, in [76] an increase in the tetraethoxysilane content of the reaction mixture with PDMS from 0 to $30 \mathrm{wt} \%$ leads to a decrease in the oxygen permeability coefficient from 640 to 185 Barrer (at 0.5 bar). It is worth noting that the properties of a membrane obtained by cross-linking depend not only on the cross-linking agent type but also on the cross-linking conditions (temperature, solvent, drying conditions, etc.) [77-79]. For example, Berean et al. [80] attribute a decrease in the methane permeability coefficient of PDMS from 1000 to 480 Barrer, observed when the cross-linking temperature was increased from 75 to $100^{\circ} \mathrm{C}$, to a decrease in the fraction of the void volume in the polymer (at 0.4 bar).

\section{DEVELOPMENT OF MIXED MATRIX MEMBRANES}

Mixed matrix membranes (MMMs) are two-phase systems. A continuous matrix of a polymer membrane material is filled with dispersed, most frequently inorganic, particles. Introduction of such particles allows altering the transport properties of a membrane material, e.g., enhancing the separation selectivity or increasing the void volume of the polymer matrix [81]. It should be noted, however, that, when preparing mixed matrix membranes, it is necessary to solve a number of problems associated with the synthesis and disintegration of particles of submicron or nanometer size, improvement of their compatibility with the polymer matrix (for uniform distribution in the matrix volume), and application of a thin flawless selective layer of the hybrid material onto a porous support.

In the first studies on the development of mixed matrix membranes based on a siloxane polymer, molecular sieves were used as fillers. Among them, the most widely used are activated zeolites (A, Y, ZSM-5, ZIF-8) [35, 36, 82-84]. Such additives allow forming additional sorption sites in the polymer matrix, which, in turn, enhances the selectivity of hydrocarbon transport through the membrane. Incorporation of a small volume fraction of inorganic fillers into a polymer matrix can considerably increase the overall separation efficiency, as predicted by the Maxwell model [85-87]. Maxwell equation (1) allows estimation of the resultant permeability of a mixed matrix membrane $\left(P_{\text {eff }}\right)$ from the fraction of inorganic particles $\left(\Phi_{d}\right)$ in the polymer and permeability of the dispersed $\left(P_{d}\right)$ and continuous $\left(P_{c}\right)$ phases [85]:

$$
P_{\text {eff }}=P_{c}\left(\frac{P_{d}+2 P_{c}-2 \Phi_{d}\left(P_{c}-P_{d}\right)}{P_{d}+2 P_{c}+2 \Phi_{d}\left(P_{c}-P_{d}\right)}\right)
$$

A pioneering study was performed by Paul and Kemp [88] and extended by Kulprathipanja et al. [89]. According to [88], introduction of $5 \mathrm{~A}$ zeolite into silicone rubber did not improve the ability of the polymer for $\mathrm{CO}_{2} / \mathrm{CH}_{4}$ separation. They also noted that introduction of particles into a silicone rubber matrix considerably increased the

PETROLEUM CHEMISTRY Vol. 61 No. 92021 
Table 1. Effect of the dispersed phase on the gas transport properties of PDMS membranes

\begin{tabular}{l|l|c|l|c}
\hline \multicolumn{1}{c|}{ Filler } & \multicolumn{1}{c|}{ Gases } & \multicolumn{1}{c|}{$\begin{array}{c}\text { Gas separation } \\
\text { selectivity }\end{array}$} & $\begin{array}{c}\text { Permeability/permeability } \\
\text { coefficient }\end{array}$ & References \\
\hline ZIF-8 (10\%) & $20 \% \mathrm{C}_{3} \mathrm{H}_{8} / 80 \% \mathrm{~N}_{2}$ & 24 & $\mathrm{C}_{3} \mathrm{H}_{8}: 1000 \mathrm{GPU}$ & {$[35]$} \\
Silicalite-1 (40\%) & $\mathrm{CO}_{2}$ and $\mathrm{N}_{2}$ & 12 & $\mathrm{CO}_{2}: 5000 \mathrm{Barrer}$ & {$[36]$} \\
Silicalite-1 $(50 \%)$ & $\mathrm{CO}_{2}$ and $\mathrm{CH}_{4}$ & 5.7 & $\mathrm{CO}_{2}: 3150 \mathrm{Barrer}$ & {$[86]$} \\
Silicalite-1 (59\%) & $\mathrm{CO}_{2}$ and $\mathrm{CH}_{4}$ & 30 & $\mathrm{CO}_{2}: 1910$ Barrer & {$[90]$} \\
5A(50\%) & $\mathrm{CO}_{2}$ and $\mathrm{CH}_{4}$ & 28 & $\mathrm{CO}_{2}: 1800$ Barrer & {$[90]$} \\
Silica nanoparticles & $15 \% \mathrm{C}_{3} \mathrm{H}_{6} / 85 \% \mathrm{~N}_{2}$ & 7.5 & $\mathrm{C}_{3} \mathrm{H}_{6}: 75 \mathrm{GPU}$ & {$[91]$} \\
POSS & $\mathrm{C}_{3} \mathrm{H}_{8}$ and $\mathrm{CH}_{4}$ & 10 & $\mathrm{C}_{3} \mathrm{H}_{8}: 10500 \mathrm{Barrer}$ & {$[95]$} \\
\hline
\end{tabular}

a 1 Barrer $=1 \times 10^{-10} \mathrm{~cm}^{3} \mathrm{~cm} \mathrm{~cm}^{-2} \mathrm{~s}^{-1}(\mathrm{~cm} \mathrm{Hg})^{-1} ; 1 \mathrm{GPU}=1 \times 10^{-6} \mathrm{~cm}^{3} \mathrm{~cm}^{-2} \mathrm{~s}^{-1}(\mathrm{~cm} \mathrm{Hg})^{-1}$.

delay time in measuring the diffusion coefficient. In their opinion, this negatively influences the membrane permeability. The first success (considerable increase in the $\mathrm{O}_{2} / \mathrm{N}_{2}$ and $\mathrm{CO}_{2} / \mathrm{CH}_{4}$ selectivity) was reached for membranes based on polydimethylsiloxane and ethylenepropylene-diene rubber with zeolite additions [90]. Duval et al. [90] showed that zeolites (silicalite-1, 13X, and KY) largely improved the characteristics of rubber polymers in $\mathrm{CO}_{2} / \mathrm{CH}_{4}$ separation. Jia et al. [86] reported an increase in the $\mathrm{O}_{2}$ permeability (from 571 to 655 Barrer at a pressure of 1 bar) and $\mathrm{O}_{2} / \mathrm{N}_{2}$ selectivity (from 2.14 to 2.92 ) on introducing silicalite-1 into silicone rubber. According to [35], introduction of ZIF-8 increases the selectivity in separation of a propane (20\%)-nitrogen $(80 \%)$ mixture at a pressure over the membrane of 2 bar from 14.5 (PDMS) to 21 (PDMS/20\% ZIF-8) but decreases the permeability from 155 to 98 GPU (gas permeation units). As shown in $[28,37]$, with an increase in the activated carbon content of the initial POMS matrix, its gas permeability increases and the $n-\mathrm{C}_{4} \mathrm{H}_{10} / \mathrm{CH}_{4}$ separation selectivity increases. The butane permeability increases with an increase in the feed pressure, and the selectivity passes through a maximum at the feed pressure of 20-30 bar. Tantekin-Ersolmaz et al. [36] observed a similar effect of a decrease in the membrane permeability with an increase in the inorganic component/polymer ratio for PDMS membranes filled with zeolites. Haesook et al. [91] introduced silica nanoparticles into the a selective layer of PDMS membranes on a polysulfone support. This allowed the propylene/nitrogen separation factor to be increased from 5.2 to 7.3. Efficient interaction of polysiloxanes and zeolites is mainly attributed in [91] to the flexibility of the polymer chain.

Recently there has been a great deal of interest in introduction of framework structures as a dispersed phase in the development of mixed matrix membranes. For example, polyhedral oligomeric silsesquioxanes (POSSs) were widely used for this purpose [92-97]. In contrast to common fillers, POSSs have a particle size of approximately $2 \mathrm{~nm}$ and a flexible structure. In addition, POSS can be functionalized with various groups bonded to external silicon atoms. Specifically diverse functional groups and good compatibility with polymers allowed POSS as an additive to find use in the development of laboratory membrane samples for pervaporation [92-94] and gas separation [95]. This is primarily associated with the fact that POSS in this case acts as both an additive and a cross-linking agent. Introduction of $40 \mathrm{wt} \%$ nanofillers based on POSS allowed the development of pervaporation membranes with enhanced levels of selectivity (7.5) and permeability $\left(300 \times 10^{3}\right.$ Barrer for $n$-butanol) for separating $1 \mathrm{wt} \% n$-butanol from water [92].

The transport properties of polysiloxane mixed matrix membranes are summarized in Table 1.

\section{SEPARATION OF GASES AND VAPORS}

Numerous gas-separation modules based on silicone rubber are used today on the pilot and commercial scale for the gas treatment and processing: Separex (UOP), Medal (Air Liquid), W.R. Grace, MTR, Permea (Air Products), and UBE Industries [4, 98, 99]. The main 
suppliers of systems for membrane separation of organic vapor/air (gas) mixtures are MTR [100] and licensiates of the Helmholtz-Zentrum Geesthacht research center (HZG, former name GKSS): Borsig, SiHi, and Dalian Eurofilm [1]. The membrane separation systems supplied by these companies are mainly used in the production of polyolefins (separation of monomers), polyvinyl chloride (off-gas treatment), ethylene oxide, and vinyl acetate (ethylene separation); in storage terminals for crude oil and petroleum products (trapping of gasoline vapors from off-gases); at compressor stations for natural gas transportation (reduction of the concentration of $\mathrm{C}_{3+}$ hydrocarbons $)^{4,5,6}$; and at small chemical and pharmaceutical enterprises [101]. The first installation for organic vapor recuperation based on membrane technologies was put into operation by GKSS GS-module in 1989 at the gasoline repository, and by 1995 already 20 membrane installations with the productive capacity of 100-2000 $\mathrm{m}^{3} \mathrm{~h}^{-1}$ were supplied to enterprises for organic vapor recuperation [101]. MTR company uses in its membrane modules membranes based on perfluorinated polymeric silicone rubbers [102]. The advantage of such polymers is their high chemical durability [4]; they are characterized by decreased solubility coefficients of gaseous hydrocarbons and do not swell or degrade in contact with petroleum products [103].

PDMS is widely used in preparation of gas-separation membranes as a finishing coating eliminating flaws $[5,6,8,104]$. Gas-transport properties of PDMS have been extensively studied. Much attention is paid in research papers to transport properties of silicone rubbers in separation of gases, including hydrocarbons. These properties were studied both for continuous films $[27,31,105,106]$ and for composite membranes [21, 107]. The permeability coefficients have been reported for the n-butane/methane pair: 930-1500 Barrer for methane and 7200-14000 Barrer for $n$-butane [27, 31, 105, 106]. The transport properties of PDMS-based systems were also

\footnotetext{
${ }^{4}$ Dalian Eurofilm Industrial Ltd. Co, P.R.China, http://eurofilm.com. cn/en/product/? id=32 (addressed June 10, 2021).

${ }^{5}$ Sterling SIHI GmbH, Gas separation by using membranes. http:// www.sterlingsihi.com/ (addressed June 10, 2021).

${ }^{6}$ BORSIG GmbH [electronic resource] / mt.borsig.de/en: BORSIG Membrane product $\mathrm{GmbH}$. http://mt.borsig.de/en/products.html (addressed June 10, 2021).
}

studied as applied to binary mixtures containing $n$-butane and multicomponent mixtures simulating the natural gas composition. Unfortunately, a considerable decrease in the PDMS selectivity in separation of gas mixtures is observed. The $n$-butane/methane permselectivity, compared to the ideal selectivity, decreases from 11 to $5[21,106]$ because of an increase in the methane permeability coefficient from 1200 to 1400 Barrer [106].

A commercial membrane based on polyoctylmethylsiloxane (POMS), developed in Germany in the GKSSForschungszentrum Geestacht $\mathrm{GmbH}$ research center (since 2010, Helmholz-Zentrum Geestacht GmbH), has been actively studied in the past decades [21, 28, 37, 108, 109]. Because POMS membranes are successfully produced on the commercial scale, their preparation procedure is not described in open sources [37]. POMS, compared to PDMS, is characterized by higher selectivity to organic vapors, as found in experiments with pure substances and on separation of hydrocarbon mixtures $[21,110]$. One of the first studies dealing with this polymer was the study by Schultz and Peinemann [21], who reported the properties of a composite POMS membrane. For example, a POMS-based membrane showed 2.4 times higher $n$-butane/methane separation selectivity (12), compared to a PDMS-based membrane (5), in separation of the binary mixture containing 3\% $n$-butane at a pressure of 10 bar [21]. In [28, 37], POMS-based mixed matrix membranes were prepared by introducing activated carbon particles into the polymer matrix. As compared to composite membranes without filler, mixed matrix membranes exhibit somewhat higher separation selectivity [22 (POMS) and 25 (POMS-MMM)] and lower permeability in separation of a 5 vol $\% n$-butane/ methane binary mixture at a pressure of 10 bar [37].

Novel membrane materials, including siloxane polymers with modified chemical structure, also attract researchers' attention. The effect of the pendant substituent (ethyl, propyl, hexyl, octyl, phenyl, 3-fluoropropyl) in the siloxane chain was studied in $[31,56]$. Lee et al. [56] reported the $\mathrm{O}_{2}$ and $\mathrm{N}_{2}$ permeability coefficients of polysiloxanes, and Schultz and Peinemann [21] also studied the transport of hydrocarbons (methane, propane) and carbon dioxide. A later study [71] deals with the correlation between the structure and transport properties of polyalkylmethylsiloxanes. It should be noted that polydecylmethylsiloxane (PDecMS), 
Table 2. Substituents on the pendant chain of polymethylsiloxane [Me(EtR)SiO $]_{n}$, studied in [29]

\begin{tabular}{l|l||l|l}
\hline Functional group R & Chemical structure & Functional group R & Chemical structure \\
\hline Acetate & $-\mathrm{CH}_{2} \mathrm{CO}_{2} \mathrm{CH}_{3}$ & Methyl phenyl ether & $-\mathrm{CH}_{2} \mathrm{OPh}$ \\
Diacetate & $-\mathrm{CH}_{\left(\mathrm{CO}_{2} \mathrm{CH}_{3}\right)_{2}}$ & Methyl ethyl ether & $-\mathrm{CH}_{2} \mathrm{OC}_{2} \mathrm{H}_{5}$ \\
Hexanoate & $-\mathrm{CH}_{2} \mathrm{CO}_{2}\left(\mathrm{CH}_{2}\right)_{4} \mathrm{CH}_{3}$ & Ethenyl & $-\mathrm{CH}_{=} \mathrm{CH}_{2}$ \\
Acetonitrile & $-\mathrm{CH}_{2} \mathrm{~N}$ & Amino & $-\mathrm{CH}_{2} \mathrm{~N}_{\left(\mathrm{CH}_{3}\right)_{2}}$ \\
Octyl & $-\left(\mathrm{CH}_{2}\right)_{7} \mathrm{CH}_{3}$ & Amido & $-\mathrm{CONH}_{2}$ \\
Benzyl & $-\mathrm{CH}_{2} \mathrm{Ph}$ & Pyridyl & $-\left(\mathrm{C}_{5} \mathrm{H}_{4} \mathrm{~N}\right)$ \\
Pentafluorobenzyl & $-\mathrm{CH}_{2} \mathrm{C}_{6} \mathrm{~F}_{5}$ & Tridecyl & $-\left(\mathrm{CH}_{2}\right)_{12} \mathrm{CH}_{3}$ \\
\hline
\end{tabular}

compared to other polyalkylmethylsiloxanes $($ alkyl $=$ hexyl, octyl), showed the highest ideal $n$-butane/ methane selectivity (27). Later [111], the separation properties of polyalkylmethylsiloxanes in separation of an eight-component model mixture of hydrocarbons, simulating the casinghead gas composition, were reported. The PDecMS-based composite membrane on MFFK-1 microporous support surpassed commercial membranes MDK-3 (Vladipor, Russia) and POMS (HZG, Germany) in separation selectivity at comparable $n$-butane permeability [111]. In particular, the $n$-butane permeability was $850 \mathrm{GPU}$, and the $n$-butane/methane selectivity was 16.7 . A promising continuation of that study is the development of hollow-fiber composite membranes [112-114]. The hollow-fiber membrane geometry allows intensification of the $n$-butane separation [115].

\section{SEPARATION OF LIQUIDS: PERVAPORATION}

Separation of liquids by hydrophobic pervaporation is mainly performed using membranes based on polysiloxanes. This separation process is primarily aimed at removal of organic substances from wastewaters from various chemical, petrochemical, pharmaceutical, and other enterprises [116]. Pervaporation is also widely used in food industry (recovery of aroma components from fruit juices) [117] and in separation of fermentation products (alcohols) in biofuel production [118]. The majority of membranes intended for hydrophobic pervaporation are made of polysiloxanes and composites based on them.
These membranes include Pervatech PDMS and $\mathrm{POMS}^{7}$, PERVAP 1070, 4060 ${ }^{8}$, POMS, MDK-3, and MTR 100, 200 [120-123].

A study by Bennett et al. [29] was one of the first studies dealing with the effect of a pendant substituent on the pervaporation properties of composite polysiloxane membranes in recovery of organic compounds from water. Bennett et al. reported the results of pervaporation recovery of phenol, chloroform, pyridine, and methyl isobutyl ketone from their mixtures with water. Bennett et al. [29] studied a series of polymers with different pendant substituents (Table 2). As they showed, the separation selectivity is considerably enhanced with an increase in the sorption of the organic component and/or a decrease in the water transport. For example, in separation of a $5 \mathrm{wt} \%$ solution of phenol in water, the PDMS membrane flux with respect to phenol was $2.15 \times 10^{-11} \mathrm{~m}^{2} \mathrm{~s}^{-1}$, and the separation factor was 17.7. The siloxane membrane with the pyridine ring in the pendant chain $(10 \%$ content of functional groups) showed the best transport properties: membrane flux with respect to phenol $5.57 \times 10^{-11} \mathrm{~m}^{2} \mathrm{~s}^{-1}$ and separation factor 31.8 . Bennett et al. note that phenol interacts with basic groups of the membrane, which enhances both the throughput and selectivity of the membrane with respect to phenol.

For removing methyl tert-butyl ether from wastewater, Borisov et al. [124] considered polyalkylsiloxanes with

\footnotetext{
${ }^{7}$ Membranes. PERVATECH. https://pervaporation-membranes. com/products/membranes/

${ }^{8}$ SULZER Chemtech. Membrane Technology. https://www. sulzer.com/-/media/files/products/process-techology/reaction technology/brochures/membrane_technology.ashx
} 
Table 3. Selectivity and permeability of Pervap 4060, POMS, and Pervatech membranes [130]

\begin{tabular}{l|c|c|c|c|c|c}
\hline \multirow{2}{*}{ Membrane } & \multicolumn{2}{|c|}{ Permeability, $\mathrm{mol} \mathrm{m}^{-2} \mathrm{~h}^{-1} \mathrm{kPa}^{-1}$} & \multicolumn{3}{c}{ Selectivity } \\
\cline { 2 - 7 } & Pervap 4060 & POMS & Pervatech & Pervap 4060 & POMS & Pervatech \\
\hline Acetone & 4.6 & 2.3 & 2.8 & 0.8 & 0.6 & 0.4 \\
Butanol & 14 & 7.2 & 6.7 & 2.0 & 0.4 & 0.7 \\
Ethanol & 4.1 & 5.3 & 3.7 & 0.9 & 0.5 & 0.4 \\
Ethyl acetate & 24.2 & 19.5 & 14.3 & 4.4 & 3.0 & 23 \\
\hline
\end{tabular}

hexyl, octyl, and decyl pendant substituents, and also composite были membranes based on them. The composite membrane based on polydecylmethylsiloxane, prepared in [124], showed the best characteristics (separation factor 310 , total flux $0.82 \mathrm{~kg} \mathrm{~m}^{-2} \mathrm{~h}^{-1}$ ) compared to the previous data [125-128]. Polydecylmethylsiloxane on MFFK-1 microfiltration support showed high selectivity in $n$-butanol recovery from water (2.8) [129].

Kujawska et al. [130] studied the pervaporation properties of Pervatech PDMS (Pervatech, Netherlands), Pervap 4060 (Sulzer Chemtech, Switzerland), and POMS (HZG, Germany) membranes in separation of binary mixtures of acetone, butanol, ethanol, and ethyl acetate with water. They noted correlation of the surface free energy of the membranes with the transport properties. The surface free energy decreases in the order Pervap $4060>$ POMS $>$ Pervatech, which leads to a decrease in the permeability with respect to the organic component and in the separation selectivity (Table 3).

The membranes based on PDMS modified with zeolites and inorganic salts appeared to be the best for the ethanol recovery [131-134]. For example, in separation of a $5 \mathrm{wt} \%$ aqueous ethanol solution at $50^{\circ} \mathrm{C}$, the maximal separation factor for the PDMS-ZSM-5/PVDF membrane (30 wt \% zeolite) was 14 at an ethanol flux of the order of $344 \mathrm{~g} \mathrm{~m}^{-2} \mathrm{~h}^{-1}$ [132]. For continuous PDMS films modified with $\mathrm{NaCl}$ and $\mathrm{Al}_{2} \mathrm{O}_{3}$, the separation factors in separation of a $5 \mathrm{wt} \%$ aqueous ethanol solution at $30^{\circ} \mathrm{C}$ are 10-11 [131].

Recovery of aroma compounds from biological media is a separate direction in the membrane science. In most cases, aroma compounds are oxygenates (esters, aldehydes, ketones, alcohols) present in low concentrations in liquids of biological origin. Pervaporation is the most promising procedure for their recovery, because, as compared to traditional extraction, it does not require auxiliary substances contaminating the foodstuffs and requiring the regeneration and additional purification. Data are available on the recovery of aroma components from orange [135], grape [136], punica [137], strawberry [138], bilberry [139], and other juices, and also from beer [140] and alcohol-free wine [141] by pervaporation using polysiloxane-based membranes. These studies demonstrated both selective concentration of aroma components and high stability of siloxane membranes in various drinks. For example, Sun et al. [141], when preparing alcohol-free wine by pervaporation through a PDMS membrane, concentrated ethanol (content in the permeate up to $50 \mathrm{vol} \%$ ) and aroma components (65-70 wt \% passed into the permeate). They also note improvement of the alcohol-free product taste after pervaporation, compared to distillation, due to deeper removal of aroma compounds (tannins, esters, acids).

Studies dealing with the development of a process for producing biobutanol in a pervaporation membrane bioreactor (integrated fermentation-pervaporation process) can be considered as a separate group of studies. They are aimed at determination of the process parameters and development of novel membranes with high operation characteristics [44, 82, 92, 142, 143]. Introduction of POSS into a polysiloxane pervaporation membrane allows a simultaneous increase in the selectivity by a factor of 2.2 and in the permeability by a factor of 3.8 , compared to the initial PDMS membrane [92]. Zhu et al. [144] note that, in butanol production in a pervaporation membrane bioreactor, introduction of fluorinated fragments into the material of polysiloxane membranes considerably reduces their plugging and enhances the stability of transport properties. The development of such membranes will allow passing to commercial implementation of the integrated fermentation-pervaporation process.

PETROLEUM CHEMISTRY Vol. 61 No. 92021 


\section{PROSPECTS FOR USING MEMBRANES BASED ON HIGH-SELECTIVITY POLYSILOXANES}

The prospects for commercial use of membrane separation are determined by the possibility of process implementation in small-size units and by low levels of power and resource consumption [145, 146]. Siloxane polymers exhibit high levels of permeability, heat resistance, and chemical stability in the majority of organic solvents. In combination with the availability of numerous modification routes to enhance the selectivity with respect to the target component, these features open prospects for very wide practical use of siloxane polymers. Their use is particularly promising in petroleum chemistry and organic synthesis for recovery from the reaction mixture and separation of reaction products, separation of homogeneous catalysts from reaction media, and fining processes (separation of sulfur-containing compounds) in oil refining. For example, Logemann et al. [147] demonstrated prospects for using a PDMS membrane for isolating hydroformylation products from reaction mixtures. Organophilic pervaporation of petroleum products on PDMS membranes also shows promise as a fining process [148, 149]. Modification of polysiloxanes can considerably expand the field of their successful use for separating various organic mixtures.

Zou et al. [150] suggested using a PDMS-based membrane with silicon dioxide and aerogel for corrosion protection of Li-ion batteries. This nonstandard use of siloxane membranes can become a new line in the studies on the development of oxygen-permeable membranes in designing metal-air batteries.

The use of siloxane membranes for nanofiltration of nonaqueous media also becomes popular [151-154]. In particular, there are studies aimed at using mixed matrix PDMS membranes for filtration of solutions of homogeneous catalysts $[153,154]$. Introduction of nanofiller (zeolite, coal, silicalite) particles reduces the membrane swelling in high-solvency liquids (toluene, ethyl acetate) and allows high (up to 98\%) catalyst retention to be reached [153].

Medicine is also an important application field of siloxane membranes owing to good biocompatibility of polysiloxanes. This field underwent active progress in the past decades. Shams et al. [155] reported the use of polyurethane/polysiloxane membranes filled with graphene oxide nanoplates as artificial skin. The bandages obtained showed good antimicrobial activity and cytocompatibility. The use of PDMS membranes for extracorporeal membrane oxygenation of blood has already became classical [156, 157]. PDMS shows good hemocompatibility, and the contact of the continuous membrane surface, in contrast to porous membranes, with blood reduces the probability of thrombus formation.

\section{CONCLUSIONS}

Polysiloxane polymers have found wide use as membrane materials for separating gases and liquids, primarily due to their high permeability, stability of transport properties, chemical durability, heat resistance, and good mechanical and film-forming properties. The unique flexibility of the polysiloxane chain and weak intra- and intermolecular interactions ensure high values of the segmental mobility and void volume of the polymer, and cross-linking ensures high mechanical properties of thin polysiloxane-based films and their stability in organic media. It should be noted that the transport and separation characteristics of polysiloxane polymers are stable in time.

Polysiloxanes allow selective recovery of bulky organic molecules from aqueous and gaseous media owing to increased dissolution selectivity in combination with low diffusion selectivity. Therefore, polysiloxane-based membranes are used for recovery of $\mathrm{C}_{3+}$ hydrocarbons from gas streams in petroleum chemistry (gas separation), treatment of air media to remove vapors of harmful organic substances (vapor separation), and recovery of valuable or contaminating organic compounds from aqueous media (pervaporation). Among polysiloxanes, polydimethylsiloxane (PDMS) is the most highly permeable; it has been studied in most detail and is the most widely used in gas separation and pervaporation. Membranes based on PDMS exhibit high throughput and high stability of transport properties, but their selectivity is insufficient for economically feasible separation of hydrocarbons.

Modification of polysiloxanes allows preparation of membranes with diverse transport properties for solving a wide range of separation problems. The onestep procedure for polysiloxane modification in the 
pendant chains is the most promising. The selectivity and permeability of polysiloxanes can be additionally enhanced by introducing microporous fillers into the polymer matrix.

The potential of using membranes of this type is high not only in traditional separation processes, but also in new fields that are being actively developed, in particular, in petroleum chemistry and organic synthesis in the context of modern trends toward power and resource saving and toward an increase in the share of largetonnage fine chemical technology.

\section{AUTHORS INFORMATION}

E.A. Grushevenko, ORCID: http://orcid.org/0000-00026643-3736

I.L. Borisov, ORCID: http://orcid.org/0000-0002-04066280

A.V. Volkov, ORCID: http://orcid.org/0000-0003-45244597

\section{FUNDING}

The study was financially supported by the Russian Foundation for Basic Research within the framework of research product no. 20-18-50134.

\section{CONFLICT OF INTEREST}

The authors declare no conflict of interest requiring disclosure in this article.

\section{OPEN ACCESS}

This article is licensed under a Creative Commons Attribution 4.0 International License, which permits use, sharing, adaptation, distribution and reproduction in any medium or format, as long as you give appropriate credit to the original author(s) and the source, provide a link to the Creative Commons license, and indicate if changes were made. The images or other third party material in this article are included in the article's Creative Commons license, unless indicated otherwise in a credit line to the material. If material is not included in the article's Creative Commons license and your intended use is not permitted by statutory regulation or exceeds the permitted use, you will need to obtain permission directly from the copyright holder. To view a copy of this license, visit http://creativecommons.org/licenses/by/4.0/.

\section{REFERENCES}

1. Baker, R.W., Membrane Technology and Research Inc., 2006, pp. 1-25.

2. Membrane Technology: in the Chemical Industry, Nunes, S.P. and Peinemann, K.V., Eds., Wiley, 2001.

3. Apel, P.Yu., Bobreshova, O.V., Volkov, A.V., Volkov, V.V., Nikonenko, V.V., Stenina, I.A., Filippov, A.N., Yampolskii, Yu.P., and Yaroslavtsev, A.B., Membr. Membr. Technol., 2019, vol. 1, no. 2, pp. 45-63. https://doi.org/10.1134/S2517751619020021

4. Bernardo, P., Drioli, E., and Golemme, G., Ind. Eng. Chem. Res., 2009, vol. 48, no. 10, pp. 4638-4663. https://doi.org/10.1021/ie8019032

5. Dibrov, G., Ivanov, M., Semyashkin, M., Sudin, V., Fateev, N., and Kagramanov, G., Fibers, 2019, vol. 7, no. 5, p. 43. https://doi.org/10.3390/fib7050043

6. Murali, R.S., Sankarshana, T., and Sridhar, S., Sep. Purif. Rev., 2013, vol. 42, no. 2, pp. 130-186.

https://doi.org/10.1080/15422119.2012.686000

7. Liu, C., Minkov, R., Faheem, S.A., Bowen, T.C., and Chiou, J.J., Patent US 8366804 B2, 2013.

8. Dibrov, G., Ivanov, M., Semyashkin, M., Sudin, V., and Kagramanov, G., Fibers, 2018, vol. 6, no. 4, p. 83. https://doi.org/10.3390/fib6040083

9. Solomakhin, V.I., Membr. Membr. Technol., 2019, vol. 1, no. 1, pp. 31-38. https://doi.org/10.1134/S2517751619070023

10. Yampolskii, Yu.P. and Volkov, V.V., J. Membr. Sci., 1991, vol. 64, pp. 191-228. https://doi.org/10.1016/0376-7388(91)80092-K

11. Dokuchaev, N.L., Talakin, O.G., Dashko, V.G., Marchenko, A.A., and Martynov, V.N., Abstracts of Papers, Membrany-98: Vserossiiskaya konferentsiya (Membranes-98: All-Russian Conf.) (Moscow, Oct. 5-10, 1998), Moscow, 1998.

12. Henis, J.M.S. and Tripodi, M.K., Patent CA 1217096 , 1984.

13. Stenina, I.A. and Yaroslavtsev, A.B., Membr. Membr. Technol., 2019, vol. 1, no. 3, pp. 137-144. https://doi.org/10.1134/S2517751619030065

PETROLEUM CHEMISTRY Vol. 61 No. 92021 
14. He, X. and Hägg, M.B., Membranes, 2019, vol. 2, no. 4, pp. 706-726.

https://doi.org/10.3390/membranes2040706

15. Baker, R.W. and Low, B.T., Macromolecules, 2014, vol. 47, no. 20, pp. 6999-7013. https://doi.org/10.1021/ma501488s

16. Brunetti, A., Melone, L., Drioli, E., and Barbieri, G., Membrane Materials for Gas and Vapor Separation: Synthesis and Application of Silicon-Containing Polymers, 2017, pp. 373-398. https://doi.org/10.1002/9781119112747.ch11

17. Gales, L., Mendes, A., and Costa, C., J. Membr. Sci., 2002, vol. 197, no. 12, pp. 211-222.

https://doi.org/10.1016/S0376-7388(01)00628-7

18. Mulder, M. and Mulder, J., Basic Principles of Membrane Technology, Springer, 1996.

19. Sampranpiboon, P., Jiraratananon, R., Uttapap, D., Feng, X., and Huang, R.Y.M., J. Membr. Sci., 2000 , vol. 174 , no. 1 , pp. 55-65. https://doi.org/10.1016/S0376-7388(00)00365-3

20. Baker, R.W. and Lokhandwala, K., Ind. Eng. Chem. Res., 2008, vol. 47, no. 7, pp. 2109-2121. https://doi.org/10.1021/ie071083w

21. Schultz, J. and Peinemann, K.V., J. Membr. Sci., 1996, vol. 110 , no. 1, pp. 37-45. https://doi.org/10.1016/0376-7388(95)00214-6

22. Dibrov, G., Ivanov, M., Semyashkin, M., Sudin, V., and Kagramanov, G., Fibers, 2018, vol. 6, no. 4, p. 83. https://doi.org/10.3390/fib6040083

23. Dvornic, P.R., Jovanovic, J.D., and Govedarica, M.N., J. Appl. Polym. Sci., 1993, vol. 49, no. 9, pp. 1497-1507. https://doi.org/10.1002/app.1993.070490901

24. Lötters, J.C., Olthuis, W., Veltink, P.H., and Bergveld, P., J. Micromech. Microeng., 1997, vol. 7, no. 3, p. 145. https://doi.org/10.1088/0960-1317/7/3/017

25. Lokhandwala, K.A., Pinnau, I., He, Z., Amo, K.D., DaCosta, A.R., Wijmans, J.G., and Baker, R.W., J. Membr. Sci., 2010, vol. 346, no. 2, pp. 270-279. https://doi.org/10.1016/j.memsci.2009.09.046

26. De Jong, J., Lammertink, R.G.H., and Wessling, M., Lab on a Chip, 2006, vol. 6, no. 9, pp. 1125-1139. https://doi.org/10.1039/B603275C

27. Merkel, T.C., Bondar, V.I., Nagai, K., Freeman, B.D., and Pinnau, I., J. Polym. Sci. B: Polym. Phys., 2000, vol. 38, no. 3, pp. 415-434. https://doi.org/10.1002/(SICI)1099-0488(20000201)38: 3\%3C415::AID-POLB8\%3E3.0.CO;2-Z
28. Mushardt, H., Kramer, V., Hülagü, D., Brinkmann, T., and Kraume, M., Chem. Ing. Tech., 2014, vol. 86, nos. 1-2, pp. 83-91.

https://doi.org/10.1002/cite.201300074

29. Bennett, M., Brisdon, B.J., England, R., and Field, R.W., J. Membr. Sci., 1997, vol. 137, nos. 1-2, pp. 633-688. https://doi.org/10.1016/S0376-7388(97)00183-X

30. Uragami, T., Yamada, H., and Miyata, T.P., J. Membr. Sci., 2001, vol. 187, nos. 1-2, pp. 2553-2569. https://doi.org/10.1016/S0376-7388(01)00355-6

31. Stern, S.A., Shah, V.M., and Hardy, B.J., J. Polym. Sci. B: Polym. Phys., 1987, vol. 25, no. 6, pp. 1263-1298. https://doi.org/10.1002/polb.1987.090250607

32. Chen, W.F. and Kuo, P.L., Macromolecules, 2007, vol. 40, no. 6, pp. 1987-1994. https://doi.org/10.1021/ma062512p

33. Uragami, T., Sumida, I., Miyata, T., Shiraiwa, T., Tamura, H., and Yajima, T., Mater. Sci. Appl., 2011, vol. 2, no. 3, p. 169.

https://doi.org/10.4236/msa.2011.23021

34. Borisov, I.L., Ushakov, N.V., Volkov, V.V., and Finkelshtein, E.Sh., Russ. Chem. Bull., 2016, vol. 65 , no. 4 , pp. $1020-1022$. https://doi.org/10.1007/s11172-016-1406-z

35. Fang, M., Wu, C., Yang, Z., Wang, T., Xia, Y., and Li, J., J. Membr. Sci., 2015, vol. 474, pp. 103-113. https://doi.org/10.1016/j.memsci.2014.09.040

36. Tantekin-Ersolmaz, Ş.B., Atalay-Oral, Ç., Tatlıer, M., Erdem-Şenatalar, A., Schoeman, B., and Sterte, J., J. Membr. Sci., 2000, vol. 175, no. 2, pp. 285-288. https://doi.org/10.1016/S0376-7388(00)00423-3

37. Mushardt, H., Müller, M., Shishatskiy, S., Membranes, 2016, vol. 6, no. 1, pp. 16-29. https://doi.org/10.3390/membranes6010016

38. Wang, J., Li, Y., Zhang, Z., and Hao, Z., J. Mater. Chem. A, 2015, vol. 3, no. 16, pp. 8650-8658. https://doi.org/10.1039/C4TA07127A

39. Yilgör, İ. and McGrath, J.E., Polysiloxane Copolymers/ Anionic Polymerization, Berlin: Springer, 1988, pp. 1-86.

40. Raigorodskii, I.M. and Gol'dberg, E.Sh., Russ. Chem. Rev., 1987, vol. 56, no. 11, pp., 1079-1095. https://doi.org/10.1070/RC1987v056n11ABEH003323

41. Noshay, A. and McGrath, J.E.. Block copolymers-overview and critical survey, New York: Academic, 1977. 
42. Ward, W.J., III, Browall, W.R., and Salemme, R.M., J. Membr. Sci., 1976, vol. 1, pp. 99-108. https://doi.org/10.1016/S0376-7388(00)82259-0

43. Park, H.B., Kim, C.K., and Lee, Y.M., J. Membr. Sci., 2002, vol. 204, nos. 1-2, pp. 257-269. https://doi.org/10.1016/S0376-7388(02)00048-0

44. Borisov, I.L., Golubev, G.S., Vasilevsky, V.P., Volkov, A.V., and Volkov, V.V., J. Membr. Sci., 2017, vol. 523, pp. 291-300.

https://doi.org/10.1016/j.memsci.2016.10.009

45. Komarova, A.B., Dubyaga, E.G., Kovylina, G.D., Karachentsev, V.G., and Tikhonova, T.Z., Vysokomol. Soedin., Ser. A, 1991, vol. 33, no. 12.

46. Beckman, I.N. and Teplyakov, V.V., Adv. Colloid Interface Sci., 2015, vol. 222, pp. 70-78. https://doi.org/10.1016/j.cis.2014.10.004

47. Saam, J.C., Ward, A.H., and Fearon, F.W.G., Polymeriz. React. New Polym., 1972, vol. 13, no. 1, pp. 524-528. https://doi.org/10.1021/ba-1973-0129.ch015

48. Matsumoto, T., Koinuma, Y., Waki, K., Kishida, A., Furuzono, T., Maruyama, I., and Akashi, M., J. Appl. Polym. Sci., 1996, vol. 59, no. 7, pp. 1067-1071. ht tps:// doi.org/10.1002/ ( S I C I) 1097 4628(19960214)59:7\%3C1067::AID-APP3\%3E3.0.CO;2-C

49. Atlaskin, A.A., Trubyanov, M.M., Yanbikov, N.R., Vorotyntsev, A.V., Drozdov, P.N., Vorotyntsev, V.M., and Vorotyntsev, I.V., J. Membr. Sci., 2019, vol. 572, pp. 92-101. https://doi.org/10.1016/j.memsci.2018.10.079

50. Semenova, S.I., Vdovin, P.A., Tarasov, A.V., Deryagina, E.E., and Maslenin, S.B., Krit. Technol. Membr., 2003, no. 4, pp. 7-17.

51. Amirkhanov, D.M., Kotenko, A.A., Rusanov, V.D., and Tul'skii, M.N., Polym. Sci., Ser. A, 1998, vol. 40, no. 2 , p. 206.

52. Kovylina, G.D., Cand. Sci. (Chem.) Dissertation, Vladimir, 1992.

53. Teplyakov, V.V., Ross. Khim. Zh., 2005, vol. 49, no. 2, pp. 41-48.

54. Finkelshtein, E.Sh., Ushakov, N.V., Krasheninnikov, E.G., and Yampolskii, Yu.P., Russ. Chem. Bull., 2004, vol. 53, no. 11, pp. 2604-2610. https://doi.org/10.1007/s11172-005-0161-3

55. Shah, V.M., Hardy, B.J., and Stern, S.A., J. Polym. Sci. B: Polym. Phys., 1993, vol. 31, no. 3, pp. 313-317. https://doi.org/10.1002/polb.1993.090310309
56. Lee, C.L., Chapman, H.L., Cifuentes, M.E., Lee, K.M., Merrill, L.D., Ulman, K.L., and Venkataraman, K., J. Membr. Sci., 1988, vol. 38, no. 1, pp. 55-70. https://doi.org/10.1016/S0376-7388(00)83275-5

57. Borisov, I.L., Ushakov, N.V., Volkov, V.V., and Finkel'shtein, E.Sh., Petrol. Chem., 2016, vol. 56, no. 6, pp. 798-804. https://doi.org/10.1134/S0965544116090024

58. Interrante, L.V., Shen, Q., and Li, J., Macromolecules, 2001, vol. 34, pp. 1545-1547. https://doi.org/10.1021/ma001785w

59. Ashworth, A.J., Bridson, B.J., England, R., Reddy, B.S.R., and Zafar, I., J. Membr. Sci., 1991, vol. 56, no. 2, pp. 217-228. https://doi.org/10.1016/S0376-7388(00)80810-8

60. Rahimian, K., Loy, D.A., and Chen, P.P., Chem. Mater., 2005, vol. 17, no. 6, pp. 1529-1534. https://doi.org/10.1021/cm048511y

61. Lohmeijer, B.G.G., Dubois, G., Leibfarth, F., Pratt, R.C., Nederberg, F., Nelson, A., Waymouth, R.M., Wade, C., and Hedrick, J.L., Org. Lett., 2006, vol. 8, no. 21 , pp. 4683-4686. https://doi.org/10.1021/o10614166

62. Kawakami, Y., Macromolecules, 1998, vol. 31, no. 17, pp. 5592-5597. https://doi.org/10.1021/ma980463d

63. Putzien, S., Nuyken, O., and Kühn, F.E., Prog. Polym. Sci., 2010, vol. 35, no. 6, pp. 687-713. https://doi.org/10.1016/j.progpolymsci.2010.01.007

64. Andrianov, K.A., Delazari, N.V., and Emel'kina, N.A., Bull. Acad. Sci. USSR, Div. Chem. Sci., 1973, vol. 22 , no. 10 , pp. 2237-2240. https://doi.org/10.1007/BF01199618

65. Petrov, A.D., Mironov, V.F., Ponomarenko, V.A., and Chernyshov, E.A., Sintez kremniiorganicheskikh monomerov (Synthesis of Organosilicon Monomers), Moscow: Akad. Nauk SSSR, 1961.

66. Ushakov, N.V., Finkel'shtein, E.Sh., Grushevenko, E.A., Volkov, V.V., and Borisov, I.L., Russ. J. Appl. Chem., 2020, vol. 93, no. 11, pp. 1646-1654. https://doi.org/10.1134/S1070427220110038

67. Raygorodsky, I., Kopylov, V., and Kovyazin, A., Membrane Materials for Gas and Vapor Separation: Synthesis and Application of Silicon-Containing Polymers, 2017, pp. 17-51. https://doi.org/10.1002/9781119112747.ch2 
68. Schatz, M., Siliconovy kaucuk (Silicon Resin), Prague: Nakl. Technicke Literatury, 1971.

69. Fritsch, D., Peinemann, K.V., Behling, R.D., and Just, R., Patent US 5595658, 1997.

70. Nyczyk, A., Paluszkiewicz, C., Hasik, M., Cypryk, M., and Pospiech, P., Vibrat. Spectrosc., 2012, vol. 59, pp. 1-8. https://doi.org/10.1016/j.vibspec.2012.01.002

71. Grushevenko, E.A., Borisov, I.L., Bakhtin, D.S., Bondarenko, G.N., Levin, I.S., and Volkov, A.V., React. Funct. Polym., 2019, vol. 134, pp. 156-165. https://doi.org/10.1016/j.reactfunctpolym.2018.11.013

72. Grushevenko, E.A., Borisov, I.L., Bakhtin, D.S., Volkov, V.V., and Volkov, A.V., Membr. Membr. Technol., 2020, vol. 2, no. 6, pp. 399-406. https://doi.org/10.1134/S2517751620060037

73. Borisov, I.L., Grushevenko, E.A., and Volkov, A.V., Membr. Membr. Technol., 2020, vol. 2, no. 5, pp. 318-324. https://doi.org/10.1134/S2517751620050030

74. Zhan, X., Li, J., Huang, J., and Chen, C., Appl. Microbiol. Biotechnol., 2010, vol. 160, pp. 632-642. https://doi.org/10.1007/s12010-008-8510-y

75. Gu, J., Bai, Y., Zhang, L., Deng, L., Zhang, C., Sun, Y., and Chen, H., Int. J. Polym. Sci., 2013, vol. 2013, article 529474 . https://doi.org/10.1155/2013/529474

76. Rao, H.X., Liu, F.N., and Zhang, Z.Y., J. Membr. Sci., 2007, vol. 303, nos. 1-2, pp. 132-139. https://doi.org/10.1016/j.memsci.2007.07.002

77. Kansara, A.M., Aswal, V.K., and Singh, P.S., RSC Adv., 2015, vol. 5, no. 64, pp. 51608-51620. https://doi.org/10.1039/C5RA06433C

78. Ogieglo, W., Van der Werf, H., Tempelman, K., Wormeester, H., Wessling, M., Nijmeijer, A., and Benes, N.E., J. Membr. Sci., 2013, vol. 437, pp. 313-323. https://doi.org/10.1016/j.memsci.2013.04.039

79. Singh, P.S., Jadav, G.L., Aswal, V.K., Das, A.K., Kumar, S., Kansara, A.M., Chaudhri, S.G., and Brahmbhatt, H., J. Appl. Polym. Sci., 2015, vol. 132, no. 7, article 41461.

https://doi.org/10.1002/app.41461

80. Berean, K., Ou, J.Z., Nour, M., Latham, K., McSweeney, C., Paull, D., Halim, A., Kentish, S., Doherty, C.M., Hill, A.J., and Kalantar-zadeh, K., Sep. Purif. Technol., 2014, vol. 122, pp. 96-104. https://doi.org/10.1016/j.seppur.2013.11.006

81. Merkel, T.C., Freeman, B.D., Spontak, R.J., He, Z., Pinnau, I., Meakin, P., and Hill, A.J., Science, PETROLEUM CHEMISTRY Vol. 61 No. 92021
2002, vol. 296, no. 5567, pp. 519-522. https://doi.org/10.1126/science.1069580

82. Liu, G., Xiangli, F., Wei, W., Liu, S., and Jin, W., Chem. Eng. J., 2011, vol. 174, pp. 495-503.

https://doi.org/10.1016/j.cej.2011.06.004

83. Pan, Y., Zhu, T., Xia, Q., Yu, X., and Wang, Y., JECE, 2020, vol. 9, no. 1, 104977.

https://doi.org/10.1016/j.jece.2020.104977

84. Chen, X., Hung, W.S., Liu, G., Lee, K.R., and Jin, W., J. Polym. Sci., 2020, vol. 58, no. 18, pp. 2634-2643. https://doi.org/10.1002/pol.20200134

85. Bouma, R.H.B., Checchetti, A., Chidichimo, G., and Drioli, E., J. Membr. Sci., 1997, vol. 128, no. 2, pp. 141-149. https://doi.org/10.1016/S0376-7388(96)00303-1

86. Jia, M., Peinemann, K.V., and Behling, R.D., J. Membr. Sci., 1991, vol. 57, nos. 2-3, pp. 289-292. https://doi.org/10.1016/S0376-7388(00)80684-5

87. Mahajan, R., Burns, R., Schaeffer, M., and Koros, W.J., J. Appl. Polym. Sci., 2002, vol. 86, no. 4, pp. 881-890. https://doi.org/10.1002/app.10998

88. Paul, D.R. and Kemp, D.R., J. Polym. Sci. Polym. Symp., 1973, vol. 41, no. 1, pp. 79-93. https://doi.org/10.1002/polc.5070410109

89. Kulprathipanja, S., Neuzil, R.W., and Li, N.N., Patent US 4740219, 1988.

90. Duval, J.M., Folkers, B., Mulder, M.H.V., Desgrandchamps, G., and Smolders, C.A., J. Membr. Sci., 1993, vol. 80, no. 1, pp. 189-198. https://doi.org/10.1016/0376-7388(93)85143-K

91. Haesook, K., Hyun-Gi, K., Sooyeon, K., and SungSoo, K., J. Membr. Sci., 2009, vol. 344, nos. 1-2, pp. 211-218. https://doi.org/10.1016/j.memsci.2009.08.004

92. Liu, G., Hung, W.-S., Shen, J., Huang, Y.-H., Jin, W., Lee, K.-R., and Lai, L.-Y., J. Mater. Chem. A, 2015, vol. 3, pp. 4510-4521. https://doi.org/10.1039/C4TA05881J

93. Zhan, X., Lu, J., Xu, H., Liu, J., Liu, X., Cao, X., and Li, J., Appl. Surf. Sci., 2019, vol. 473, pp. 785-798. https://doi.org/10.1016/j.apsusc.2018.12.093

94. Liu, Y., Hu, T., Zhao, J., Lu, L., Muhammad, Y., Lan, P., He, R., Zou, Y., and Tong, Z., J. Membr. Sci., 2019, vol. 591, 117324. https://doi.org/10.1016/j.memsci.2019.117324

95. Rezakazemi, M., Vatani, A., and Mohammadi, T., J. Nat. Gas Sci. Eng., 2016, vol. 30, pp. 10-18. https://doi.org/10.1016/j.jngse.2016.01.033 
96. Zhang, D., Liu, Y., Shi, Y., and Huang, G., RSC $A d v ., 2014$, vol. 4, no. 12, pp. 6275-6283. https://doi.org/10.1039/C3RA46711B

97. Le, N.L., Tang, Y.P., and Chung, T.S., J. Membr. Sci., 2013, vol. 447, pp. 163-176. https://doi.org/10.1016/j.memsci.2013.07.021

98. Solov'ev, S.A. and Polyakov, A.M., Ser. Krit. Tekhnol. Membr., 2006, no. 3, pp. 31-32.

99. Hale, P. and Lokhandwala, K., Proc. Laurance Reid Gas Conditioning Conf., 2004, pp. 165-180. https://www.mtrinc.com/wp-content/uploads/2018/09/ NG02-GPA2004FinalPaper.pdf

100. Van Hecke, W. and De Wever, H., J. Membr. Sci., 2017, vol. 540, pp. 321-332. https://doi.org/10.1016/j.memsci.2017.06.058

101. Peinemann, K.V. and Ohlrogge, K., Separation of organic vapors from air with membranes, Membrane Processes in Separation and Purification, Dordrecht: Springer, 1994, pp. 357-372. https://doi.org/10.1007/978-94-015-8340-4_17

102. Baker, R.W., Pinnau, I., He, Z., Amo, K.D., Da Costa, A.R., and Daniels, R., Patent US 6579341, 2003.

103. Yampol'skii, Yu.P., Russ. J. Gen. Chem., 2009, vol. 79, pp. 657-665. https://doi.org/10.1134/S1070363209030475

104. Henis, J.M.S. and Tripodi, M.K., J. Membr. Sci., 1981, vol. 8, no. 3, pp. 233-246. https://doi.org/10.1016/S0376-7388(00)82312-1

105. Pinnau, I. and He, Z., J. Membr. Sci., 2004, vol. 244, pp. 227-233. https://doi.org/10.1016/j.memsci.2004.06.055

106. Raharjo, R.D., Freeman, B.D., Paul, D.R., Sarti, G.C., and Sanders, E.S., J. Membr. Sci., 2007, vol. 306, no. 1, pp. 75-92.

https://doi.org/10.1016/j.memsci.2007.08.014

107. Singh, A., Freeman, B.D., and Pinnau, I., J. Polym. Sci. B: Polym. Phys., 1998, vol. 36, no. 2, pp. 289-301. https://doi.org/10.1002/(SICI)1099-0488(19980130)36: 2\%3C289::AID-POLB8\%3E3.0.CO;2-M

108. Liu, L., Huang, D., and Yang, F., Sep. Purif. Technol., 2009, vol. 66, no. 2, pp. 411-416. https://doi.org/10.1016/j.seppur.2008.12.023

109. Abetz, V., Brinkmann, T., Dijkstra, M., Ebert, K., Fritsch, D., Ohlrogge, K., Paul, D., Peinemann, K.-V., Nunes, S.P., Scharnagl, N., and Schossig, M., Adv. Eng.
Mater., 2006, vol. 8, no. 5, pp. 328-358. https://doi.org/10.1002/adem.200600032

110. Ohlrogge, K., Wind, J., Brinkmann, T., Scheel, H., Stegger, J., and Tiberi, T., Comprehensive Membrane Science and Engineering, Oxford: Elsevier, 2017, 2nd ed., vol. 2, pp. 226-255. https://doi.org/10.1016/B978-0-12-409547-2.12216-4

111. Grushevenko, E.A., Borisov, I.L., Knyazeva, A.A., Volkov, V.V., and Volkov, A.V., Sep. Purif. Technol., 2020, vol. 241, 116696. https://doi.org/10.1016/j.seppur.2020.116696

112. Matveev, D.N., Vasilevsky, V.P., and Kutuzov, K.A., Key Eng. Mater., 2020, vol. 869, pp. 443-448. https://doi.org/10.4028/www.scientific.net/KEM.869.443

113. Wang, D., Teo, W.K., and Li, K., J. Membr. Sci., 2002, vol. 204, nos. 1-2, pp. 247-256. https://doi.org/10.1016/S0376-7388(02)00047-9

114. Sethunga, G.S.M.D.P., Karahan, H.E., Wang, R., and Bae, T.H., J. Membr. Sci., 2019, vol. 584, pp. 333-342.

https://doi.org/10.1016/j.memsci.2019.05.016

115. Kirsch, V.A. and Bazhenov, S.D., Sep. Purif. Technol., 2020, vol. 242, 116834.

https://doi.org/10.1016/j.seppur.2020.116834

116. Figoli, A., Santoro, S., Galiano, F., and Basile, A., Pervaporation, Vapour Permeation and Membrane Distillation, Woodhead, 2015, pp. 19-63. https://doi.org/10.1016/B978-1-78242-246-4.00002-7

117. Bhattacharjee, C., Saxena, V.K., and Dutta, S., Innov. Food Sci. Emerg. Technol., 2017, vol. 43, pp. 136-153.

https://doi.org/10.1016/j.ifset.2017.08.002

118. Vane, L.M., J. Chem. Technol. Biotechnol., 2005, vol. 80 , no. 6, pp. 603-629. https://doi.org/10.1002/jctb.1265

119. Kujawska, A., Knozowska, K., Kujawa, J., and Kujawski, W., Sep. Purif. Technol., 2016, vol. 159 , pp. $68-80$. https://doi.org/10.1016/j.seppur.2015.12.057

120. Golubev, G.S., Borisov, I.L., and Volkov, V.V., Russ. J. Appl. Chem., 2018, vol. 91, no. 8, pp. 1375-1831. https://doi.org/10.1134/S1070427218080177

121. Huang, J. and Meagher, M.M., J. Membr. Sci., 2001, vol. 192, pp. 231-242. https://doi.org/10.1016/S0376-7388(01)00507-5

122. Jonquières, A., Clément, R., Lochon, P., Néel, J., Dresch, M., and Chrétien, B., J. Membr. Sci.,

PETROLEUM CHEMISTRY Vol. 61 No. 92021 
2002, vol. 206, nos. 1-2, pp. 87-117.

https://doi.org/10.1016/S0376-7388(01)00768-2

123. Volkov, V., Borisov, I., Golubev, G., Vasilevsky, V., Matveev, D., Bondarenko, G., and Volkov, A., J. Chem. Technol. Biotechnol., 2020, vol. 95, no. 1 , pp. 40-51.

https://doi.org/10.1002/jctb.6196

124. Borisov, I., Podtynnikov, I., Grushevenko, E., Scharova, O., Anokhina, T., Makaev, S., Volkov, A., and Volkov, V., Polymers, 2020, vol. 12, no. 6, p. 1213. https://doi.org/10.3390/polym12061213

125. Kujawa, J., Cerneaux, S., and Kujawski, W., Chem. Eng. J., 2015, vol. 260, pp. 43-54. https://doi.org/10.1016/j.cej.2014.08.092

126. Kujawa, J., Cerneaux, S., and Kujawski, W., J. Membr. Sci., 2015, vol. 474, pp. 11-19.

https://doi.org/10.1016/j.memsci.2014.08.054

127. Yoshida, W. and Cohen, Y., J. Membr. Sci., 2004, vol. 229, pp. 27-32. https://doi.org/10.1016/j.memsci.2003.09.021

128. Kujawski, W. and Roszak, R., Sep. Sci. Technol., 2002, vol. 37, no. 15, pp. 3559-3575. https://doi.org/10.1081/SS-120014443

129. Grushevenko, E.A., Podtynnikov, I.A., and Borisov, I.L., Russ. J. Appl. Chem., 2019, vol. 92, no. 11, p. 1593.

https://doi.org/10.1134/S1070427219110168

130. Kujawska, A., Knozowska, K., Kujawa, J., and Kujawski, W., Sep. Purif. Technol., 2016, vol. 159, pp. $68-80$.

https://doi.org/10.1016/j.seppur.2015.12.057

131. Kujawska, A., Knozowska, K., Kujawa, J., Li, G., and Kujawski, W., Sep. Purif. Technol., 2020, vol. 234, 116092.

https://doi.org/10.1016/j.seppur.2019.116092

132. Zhan, X., Li, J.D., Chen, J., and Huang, J.Q., J. Polym. Sci., 2009, vol. 27, no. 06, pp. 771-780. https://doi.org/10.1142/S0256767909004485

133. Dobrak, A., Figoli, A., Chovau, S., Galiano, F., Simone, S., Vankelekom, I.F.J., Drioli, E., and Van der Bruggen, B., J. Colloid Interface Sci., 2010, vol. 346, no. 1, pp. 254-264. https://doi.org/10.1016/j.jcis.2010.02.023

134. Vankelecom, I.F.J., Depre, D., De Beukelaer, S., and Uytterhoeven, J.B., J. Phys. Chem. B, 1995, vol. 99, no. 35, pp. 13193-13197. https://doi.org/10.1021/j100035a024

PETROLEUM CHEMISTRY Vol. 61 No. 92021
135. Shepherd, A., Habert, A.C., and Borges, C.P., Desalination, 2002, vol. 148, nos. 1-3, pp. 111-114. https://doi.org/10.1016/S0011-9164(02)00662-8

136. Rajagopalan, N. and Cheryan, M., J. Membr. Sci., 1995, vol. 104, no. 3, pp. 243-250. https://doi.org/10.1016/0376-7388(95)00039-F

137. Raisi, A., Aroujalian, A., and Kaghazchi, T., J. Membr. Sci., 2008, vol. 322, no. 2, pp. 339-348.

https://doi.org/10.1016/j.memsci.2008.06.001

138. Isci, A., Sahin, S., and Sumnu, G., J. Food. Eng., 2006, vol. 75, no. 1, pp. 36-42.

https://doi.org/10.1016/j.jfoodeng.2005.03.048

139. Diban, N., Urtiaga, A., and Ortiz, I., Desalination, 2008, vol. 224, no. 1, pp. 34-39.

https://doi.org/10.1016/j.desal.2007.04.076

140. Catarino, M., Ferreira, A., and Mendes, A., J. Membr. Sci., 2009, vol. 341, nos. 1-2, pp. 51-59.

https://doi.org/10.1016/j.memsci.2009.05.038

141. Sun, X., Dang, G., Ding, X., Shen, C., Liu, G., Zuo, C., Chen, X., Xing, W., and Jin, W., Food Bioprod. Process, 2020, vol. 123, pp. 262-273.

https://doi.org/10.1016/j.fbp.2020.07.006

142. Chen, G., Zhu, H., Hang, Y., Liu, Q., Liu, G., and Jin, W., AIChE J., 2019, vol. 65, e16773.

https://doi.org/10.1002/aic.16773

143. Zhu, H., Liu, G., Yuan, J., Chen, T., Xin, F., Jiang, M., Fan, Y., and Jin, W., Sep. Purif. Technol., 2019, vol. 229, 115811.

https://doi.org/10.1016/j.seppur.2019.115811

144. Zhu, H., Li, X., Pan, Y., Liu, G., Wu, H., Jiang, M., and Jin, W., J. Membr. Sci., 2020, vol. 609, 118225. https://doi.org/10.1016/j.memsci.2020.118225

145. Scholes, C.A., Front. Chem. Sci. Eng., 2020, pp. 1-12.

https://doi.org/10.1007/s11705-019-1860-x

146. Chang, H., Li, T., Liu, B., Vidic, R.D., Elimelech, M., and Critttenden, J., Desalination, 2019, vol. 455, pp. 34-57.

https://doi.org/10.1016/j.desal.2019.01.001

147. Logemann, M., Alders, M., Wis, M., Pyankova, V., Krakau, D., Gottschalk, D., and Wessling, M., J. Membr. Sci., 2020, vol. 615, 118334. https://doi.org/10.1016/j.memsci.2020.118334

148. Qi, R., Wang, Y., Li, J., Zhao, C., and Zhu, S., J. Membr. Sci., 2006, vol. 280, nos. 1-2, pp. 545-552. https://doi.org/10.1016/j.memsci.2006.02.008 
149. Mortaheb, H.R., Ghaemmaghami, F., and Mokhtarani, B., Chem. Eng. Res. Des., 2012, vol. 90 , no. 3, pp. 409-432.

https://doi.org/10.1016/j.cherd.2011.07.019

150. Zou, X., Liao, K., Wang, D., Lu, Q., Zhou, C., He, P., Ran, R., Zhou, W., Jin, W., and Shao, Z., Energy Storage Mater., 2020, vol. 27, pp. 297-306. https://doi.org/10.1016/j.ensm.2020.02.014

151. Stafie, N., Stamatialis, D.F., and Wessling, M., Sep. Purif. Technol., 2005, vol. 45, no. 3, pp. 220-231. https://doi.org/10.1016/j.seppur.2005.04.001

152. Soltane, H.B., Roizard, D., and Favre, E., J. Membr. Sci., 2013, vol. 435, pp. 110-119. https://doi.org/10.1016/j.memsci.2013.01.053

153. Gevers, L.E.M., Vankelecom, I.F.J., and Jacobs, P.A., J. Membr. Sci., 2006, vol. 278, nos. 1-2, pp. 199-204.

https://doi.org/10.1016/j.memsci.2005.10.056
154. Pinheiro, A.F.M., Hoogendoorn, D., Nijmeijer, A., and Winnubst, L., J. Membr. Sci., 2014, vol. 463, pp. 24-32.

https://doi.org/10.1016/j.memsci.2014.03.050

155. Shams, E., Yeganeh, H., Naderi-Manesh, H., Gharibi, R., and Hassan, Z.M., J. Mater. Sci. Mater. Med., 2017, vol. 28, no. 5, p. 75.

https://doi.org/10.1007/s10856-017-5881-z

156. Lequier, L., Horton, S.B., McMullan, D.M., and Bartlett, R.H., Pediatr. Crit. Care Med., 2013, vol. 14 , no. 501, p. S7.

https://doi.org/10.1097/PCC.0b013e318292dd10

157. Evseev, A.K., Zhuravel, S.V., Alentiev, A.Yu., Goroncharovskaya, I.V. and Petrikov, S.S., Membr. Membr. Technol., 2019, vol. 1, no. 4, pp. 201-211. https://doi.org/10.1134/S2517751619040024 